\title{
Embodied Representation: Audiovisual Media and Sensory Ethnography
}

\section{Lorenzo Ferrarini}

\section{(2) OpenEdition}

\section{Journals}

\section{Electronic version}

URL: http://journals.openedition.org/anthrovision/2514

DOI: 10.4000/anthrovision.2514

ISSN: 2198-6754

\section{Publisher}

VANEASA - Visual Anthropology Network of European Association of Social Anthropologists

Electronic reference

Lorenzo Ferrarini, «Embodied Representation: Audiovisual Media and Sensory Ethnography », Anthrovision [Online], 5.1 | 2017, Online since 30 June 2017, connection on 02 May 2019. URL : http:// journals.openedition.org/anthrovision/2514; DOI : 10.4000/anthrovision.2514

This text was automatically generated on 2 May 2019.

(c) Anthrovision 


\title{
Embodied Representation: Audiovisual Media and Sensory Ethnography ${ }^{1}$
}

\author{
Lorenzo Ferrarini
}

\section{Introduction}

1 This article starts from a simple question: what makes an audiovisual ethnography a piece of sensory ethnography? With this latter term I refer to part of a debate that originated from the so-called "sensory turn" in anthropology, which developed a specific interest in the relevance of sensory perception for human experience since the end of the 1980s. Scholars like David Howes, Paul Stoller, Constance Classen, Nadia Seremetakis, Steven Feld and others have, with different approaches, asked how our experience is shaped by culturally specific patterns of sensory perception. In part as a reaction to the increasing emphasis on textuality derived from the "writing cultures" movement (Clifford and Marcus 1986), they underlined how cultures also had other experiential dimensions that were less easy to transcribe and translate into text (Jackson 1989; Stoller 1997).

2 Despite the apparent uniformity suggested by labels such as sensory turn, though, most of these scholars are only loosely tied together by an interest in perception. In fact they took at least two different directions, one of which is commonly labelled anthropology of the senses. Its starting point was a critique of the emphasis of Western culture on vision as a privileged modality for knowing. Fabian (1983) linked visualism to the power discourse of colonialism. Feld (1982) and Stoller (1984) underlined the relevance sound has for the cultures in which they worked. The group of the Centre for Sensory Studies at the Concordia University in Montreal concentrated on differences and transformations in the sensorium - the range, segmentation and organisation of the senses (see especially Howes 1991; Howes 2005; Classen 1993; Smith 2007). This group adopted a historical and comparative approach, also following the work of historians like Corbin $(1986 ; 1998)$ or 
Porter (Bynum and Porter 1993; Porter 2005). Howes (1991) looked at how the senses are attributed value and their connections with social organisation, class and worldviews. Classen (1993) in particular has underlined some key historical moments that redefined the hierarchy between the senses.

Tim Ingold has critiqued these approaches to the anthropology of the senses, and underlines how studying the configurations of the sensorium reinforces the illusion of a separation between the senses. In particular, he argues against those who, like Howes and Classen, identify a given sensory modality with a culture - for example visualism as intrinsically Euro-American - and derive from it a dominant way of apprehending the world - in the case of vision, detachment and domination (Ingold 2000: 281-82). Instead, vision does not entail in itself a given attitude towards the world because it is not in the first place essentially separate from other senses - such as hearing, to which it is often opposed. But the most fundamental problem with the anthropology of the senses for Ingold is its cultural constructionist approach that explains the diversity of the ways we apprehend the world with the elaboration of a flux of raw data of experience. Vision then becomes conceived as a mirror for visualisation, the representationalist paradigm whereby by perceiving we create internal representations of an external reality (Ingold 2000: 282-293). This paradigm rests firmly on the Cartesian dualism between mind and body, even in apparent contradiction with the epistemological principles of the anthropologists of the "sensory turn."

4 Michael Herzfeld (2001: 252), in a chapter dedicated to the senses in anthropology, has argued that the discipline should not make of the sensorium another sub-field of studies yet another anthropology-of. Rather the senses should become a method and a perspective to apply across the discipline. Some scholars have indeed tried to develop an anthropology through the senses, or a sensate anthropology or a sensory ethnography. In other words, they have reflected on the role of the embodied, sensuous experience of the ethnographer as a way to access local sensory cultures. It is important to remember that this happened in a period that saw, in anthropology and beyond, the rise of an interest for the body and embodiment, and of perspectives inspired by phenomenology (Csordas 1990; 1994; Jackson 1996; Kirmayer 1992; Scheper-Hughes and Lock 1987). Paul Stoller (1997) put forward a call for a "sensuous scholarship" and employed his experiences of apprenticeship with a Songhay sorcerer during which he experimented on his own skin the rivalries between sorcerers, and became the victim of a magical attack that left him temporarily paralysed (Stoller and Olkes 1987; Stoller 1989). More examples can be found in the fields of the anthropology of emotions (Desjarlais 1992; Hage 2009; Newmahr 2008; Rosaldo 1984), every-day life (Jackson 1983; Pink 2004; Seremetakis 1996), martial arts and boxing (Bar-On Cohen 2009; Cox 2011; Kohn 2001; Wacquant 1995; 2004), dance (Downey 2011; Taylor 1998; Wulff 1998 Roseman) and music (Rice 1994; Roseman 1993).

5 I should add that the opposition between an anthropology of the senses and sensory ethnography, although generally agreed upon by various scholars, is itself the subject of a debate that sees Howes, rejecting the characterisation of his work and even the label of anthropology of the senses, as opposed to Sarah Pink (Pink and Howes 2010). Nonetheless, I will use the distinction for practical purposes, emphasising my concern here with ethnographic media that stress the evocation of sensory experience in the audience and the inscription of the body of the filmmaker or sound recordist in the piece itself. Films about the body (MacDougall 2006, 13-20) or the senses represent in this context an analogy with an anthropology of the senses and are less relevant to this discussion. This 
article is, in other words, concerned with the potential for a sensory documentary practice to put into practice the same premises on embodiment, inspired by phenomenology that kicked off sensory ethnography. These include contesting models of perception and cognition derived from the Cartesian split between mind and body, and paying attention to modes of experience that are less linguistic, symbolic and semiotic than they are sensory, embodied or "beyond text" (Cox, Irving, and Wright 2016).

\section{Audiovisual Media and Sensory Perception}

One of the main contributions to the idea that images and sounds can provide anthropology with a form of knowledge that is alternative to that conveyed by text is represented by David MacDougall's book The Corporeal Image (2006). Bringing together his multiple decades of reflections on ethnographic film and his recent filmic work, he acknowledges that our way of seeing is partly metaphorical and linguistic. Nonetheless, vision is also literal or, for MacDougall, relates to being as well as to meaning. Knowledge of the senses is one of the best channels to understand other people's experience, in a completely different way to words. The latter are mainly aimed at an explanation, while images embrace a complexity, along with a component of meaning that refuses explanation and dissection by rationalist thought (MacDougall 2006: 5). But way too often, in anthropology, the knowledge of the senses is considered an accessory to reach more abstract formulations, a way to "[...] preserve the value of knowledge as meaning, but [...] miss an opportunity to embrace the knowledge of being" (MacDougall 2006: 6). MacDougall asks phenomenologically to go back to things themselves, worried that a continuous imposition of meaning and the search for a code to decipher, hidden underneath experience, may prevent the subject from opening up to the object through an affection of the senses that precedes abstract thought.

7 Film and audio recordings, he writes, unfold through time mimicking the temporality of experience. Writing, on the contrary, is usually oriented toward an explanation, a completeness not necessarily reached by recording. Furthermore, recordings preserve important deictic characteristics, for they are testimonies of moments of the author's seeing and listening - they carry the mark of the author's body in their own being (54). Similarly the filmic subjects, the persons who represent the very MacDougall 2006: source of anthropological knowledge, are not subjected by recordings to those generalizations that normally accompany writing. Film shows their being unique persons, and sometimes even the encounter with the anthropologist's own individuality.

But, most importantly, the main difference between writing and film, for MacDougall, lies in the latter's sensory qualities. The power of a close-up to evoke tactile characteristics, that of a wide angle to suggest three-dimensionality or that of a telephoto lens to flatten perspective, all confer materiality to images, a dimension writing can hardly render. So films "recover a dimension often lost in texts. This impinges on the viewer in various ways - as hyperawareness, shock, and pleasure" (MacDougall 2006: 58).

Sometimes MacDougall's opposition of film and writing seems to downplay the possibility for differences in approach that are transversal to both writing and film. Film, for example, can be highly intellectual in its construction and even para-linguistic in the principles of its editing. Classic examples are the Soviet tradition of intellectual montage (Bordwell 1993) and many essay films (Corrigan 2011). On the other hand Paul Stoller (1992: 203-4) has argued for taking a similar approach to anthropological writing to what 
MacDougall proposes for film. Howes (2003: 57) even argued that writing's peculiarity of not soliciting directly a single sensory modality achieves a balance between the senses that film breaks, privileging sight over for example smell.

Associating images and sounds with sensory perception in too direct a way can lead to criticism by those who, like Ingold, stress perception as entanglement of an organism with its environment, rather than a process of creation of internal representations. Intervening in the debate between Howes and Pink mentioned above, Ingold (2011b: 315) criticised the anthropology of the senses for implicitly equating eyes, ears and skin with instruments of playback. The anthropology of the senses is then for Ingold a form of cultural studies concerned with sensory imaginations and has little to say about how people phenomenologically experience the world they inhabit. On these same grounds, Ingold is critical of the use of documentary films and sound recordings to address an interest in sensory perception, proposing instead practices of drawing and walking (2004; 2007; 2011a). In this he relies, as he did throughout his work, on the ideas of psychologist James J. Gibson and his conception of ecological perception.

Gibson was in fact very critical of the experiments carried by many of his colleagues of the post-war period, which involved constraints of the field of view or shutters to impose a monocular point of observation. He called this restricted vision snapshot or aperture, and pointed out how only in these artificial conditions human vision resembled the functioning of a photographic camera. Our vision is normally binocular, whereas when we look at reproduced images we deal with a flat surface showing a monocular point of view (Gibson 1979: Chapters 15-16). He was also very critical of the mainstream theory of retinal images, and of the existence of mental processes tasked with reconstructing the world's characteristics of luminosity and hue, relying on intensity and wavelength of the visible light.

12 For Gibson, instead, vision is the interactive experience of a visual world by perceptual systems. Unlike sensory modalities, perceptual systems are multisensory experiences aggregated by functional references (Gibson 1966). The environment plays for Gibson a much more important role than it was for classical optics, so much so that at the beginning of his main work, The Ecological Approach to Visual Perception (1979), he underlines how animal and environment share a relationship of mutual dependence, and how the former would not exist without the latter. Gibson is not denying the existence of the physical world, but he makes a point of emphasizing how this is different from an environment, which is bound to the presence of an animal experiencing it (1979: 8). Through phenomenological ${ }^{2}$ moves, such as the elaboration of the concept of affordance, Gibson posits knowledge as an extension of perceiving (1979: 258). For him the perceiver is not to be considered a passive receiver, applying a creative-interpretive process to raw data, but rather an active perceiver, whose activity is recognizing information already contained in events, themselves enough to allow cognition.

Recordings cannot be substituted to perception because the latter contains endless information. At best, they can be the subject of perception. This way representation is never re-presentation, because it cannot be compared, for complexity and layering, to perception (Gibson 1979: 279). It is not just a matter of the quantity of information, but rather about the kind of intervention a perceptual system operates on its environment: if the animal-recording interaction is substituted to the animal-environment one, it changes from the qualitative point of view, becoming a second-hand description. 
14 If we acknowledge these differences, is it possible at all to represent or even evoke perception with tools - a camera, a microphone - that work in such a different way from the way we perceive? It is now time to qualify the question I posed at the beginning, since I am here suggesting that an audiovisual ethnography is not a sensory ethnography simply by virtue of being made of images and/or sounds. A better formulation would be: "What approaches to audiovisual recordings can make them a sensory ethnography true to the principles of phenomenological and ecological perception?".

\section{Recording With the Body}

15 In this section I review some ways of suggesting and evoking the corporeality of the recording person, rather than analysing the reception of the work by the viewer. In coherence with the principles of sensory anthropology of using embodiment and the senses as a method, the works that I will present revolve around the experience in the first person of their makers. One of these authors, Steven Feld, is a protagonist of the sensory turn, and among his media production I will concentrate here on his post-2000 sound recordings. The other figure, Jean Rouch, can be considered a precursor of the anthropological interest for the senses (see Stoller 1992). The aspect of his work that I find relevant for this discussion is his conception of camerawork as performance and technique of the body, evident in his filmic practice and in some of his writings. Both Rouch and Feld in common seem to counter the assumption whereby to speak to human perception a recording must draw as little attention as possible on style, editing and camera/microphone work. Such a principle is one of the basics of observational cinema (Grimshaw and Ravetz 2009; MacDougall 2016) and is taken for granted even in proposals to go beyond such realist traditions (for example Suhr and Willerslev 2012: 283-85). According to an ecological and phenomenological conception of perception, such a realist recording style is the farthest from human perception, and it makes little sense to treat recordings as deferred perception (Gibson 1979, 279). But instead of rejecting the usefulness of audiovisual media to portray perception in the light of Gibson's ideas, as Ingold does, I propose to look at the way specific technologies and recording techniques were developed by Rouch and Feld to evoke embodied and sensory experience. After all Gibson, who is otherwise very critical of still photography in any analogy with vision, is more positive in his analysis of film (Gibson 1979, Chapter 16). I suggest that a creative intervention is required to get closer to bridging the gap between recordings and perception, steering away from a filmic (or phonographic) plain style that mostly relies on the viewer treating the screen (or the loudspeakers) as a window on reality. It has already been suggested that some of the languages of experimental film, for example, might be truer to the fragmentation and variety of sensory experience (Heuson and Allen 2014: 120).

Here I stress interventions in the recording phase, rather than during editing. These interventions start in the way bodily perception is used to guide recording. Rouch, similarly to other documentary camera operators, would keep the eye that was not on the viewfinder open, so as to link the images projected on the groundglass, surrounded in black and flattened, with the perception of the other eye, more connected to the sensory world. Feld on the other hand developed in his recent research a recording technique that does away with monitors: his ears are used critically to get an idea of the acoustic image the microphones will render. These apparently marginal details constitute in my 
opinion the precondition for a phenomenological recording style, underlining the way these researcher are plunged in the sensory complexity of their fieldsites, instead of seeking isolation in a monitoring device.

This factor, together with the choice of the recording equipment, helps to suggest to the viewer the presence of a recording body in the scene. At the beginning of the 1960s Jean Rouch was part of the process of developing lightweight and quiet film cameras with sync-sound capabilities. Previous models implied a choice between hand-holding and heavy blimps to isolate their noisy motors. However, since the descent of the river Niger in 1946-47, when he lost the tripod he carried for his Bell \& Howell, Rouch tried to make as much as possible without any fixed support for his cameras - which at the time meant renouncing to sync-sound. At the end of the fifties, in North America, the first experiments with shoulder-mounted cameras were started. Rouch was among the first to import these techniques in France and in anthropological cinema, and during the shooting of Chronique d'un été (1960) he worked with Eclair's engineers Coutant and Beauviala on a silent, lightweight camera that could be handheld and use sync-sound. He also hired cameraman Michel Brault of the National Film Board of Canada, who was pioneering the technique of walking with the camera (Henley 2009: 157-62). This point is particularly important, as it allows a parallel to be drawn with Gibson's idea of the perceiver in dynamic exploration of the environment. Rouch, quoting Dziga Vertov, ideally saw the camera and man as an integrated system moving close to the people it was filming (2003b: 38-39). For the same reason he often preferred fixed focal lengths, especially wide-angles. Zoom lenses for him were a kind of voyeuristic arrogance, to be perceived by those filmed as much as from subsequent viewers of the film. On the contrary, for him:

The only way to film is to walk with the camera, taking it where it is most effective and improvising another type of ballet with it, trying to make it as alive as the people it is filming. I consider this dynamic improvisation to be a first synthesis of Vertov's ciné-eye and Flaherty's participating camera. I often compare it to the improvisation of the bullfighter in front of the bull. Here, as there, nothing is known in advance; the smoothness of a faena is just like the harmony of a traveling shot that articulates perfectly with the movements of those being filmed. In both cases as well, it is a matter of training, mastering reflexes as would a gymnast. (Rouch 2003b: 38-39)

From this excerpt clearly transpires how filming was for Rouch a technique of the body, made up of learning specific procedures. Using a fixed focal length means to have to operate choices with the cameraman's own movements, at the same time making the viewers conscious of a spatially active presence. While Henley reads his attempts to make a film that corresponds to single sequence shot as a strategy to free himself from the burden of editing (2009: 269-74), he also recognises that the dimension of unrepeatable, inspired performance was a central motivation. Coherently, Rouch's camerawork pedagogy was aimed at making students aware of their own body and of the use they can do of it while filming: he taught how to use parts of the body as anchors and how to be conscious of the body's limits in the world. ${ }^{3}$

Vertov is also the inventor of the concept of kinopravda, translated in French as ciné-verité, meaning that peculiar reality portrayed by the eye of the camera as a technological organ, the ciné-œil (1924). A distorted, processed, empowered truth: a filmic truth. To be for the film, to move, to look and to listen on the basis of the film - ciné-penser represents a particular state of consciousness, a kind of trance. In front of those present 
at a possession ceremony the filmmaker's self is transformed, for when the camera motor runs his behaviour radically changes.

For the Songhay-Zarma, who are now quite accustomed to film, my "self" is altered in front of their eyes in the same way as is the "self" of the possession dancers: it is the "film-trance" (ciné-transe) of the one filming the "real trance" of the other. This experience is really true to me, and I know by the control of my camera eyepiece, by the reactions of the audience, whether the filmed sequence is a success or a failure and whether I have been able to free myself of the weight of filmic and ethnographic theories necessary to rediscover the barbarie de l'invention. (Rouch 2003a: 99-100)

He does not speak anymore, except for the signals directed to his assistant. His perception is technologically mediated, he looks through a machine and listens thanks to a kind of prosthesis. Given these abnormal conditions, he can become a participant to the ceremony, filming trance from a ciné-transe state. In a sense, his activity is similar to that of the sorcerer hunting spirits, with the technological help of a camera and a microphone. This hypothesis seems to be confirmed when, projecting the finished documentaries in the communities where they were filmed, possession episodes occurred during the screening. Rouch writes about the experience undergone by the self of the ethnographer, revealing how the concept of ciné-transe represents a very early example of corporeal reflexivity and of radically anti-Cartesian observant participation (2003a: 543).

21 Steven Feld has chosen a specific kind of microphones for most of his recordings of the 2000s, two omnidirectional capsules called by their inventor DSM - Dimensional Stereo/ Surround Microphones. ${ }^{4}$ They employ the modification of sound frequencies performed by the listener's head - Head Related Transfer Function, HRTF - in order to record sound with a marked presence, depth and spatial effect. In order to work properly, these small microphones are to be worn to the side of one's head, as close as possible to the ears. Unlike binaural microphones, which use to a similar effect the shape of the external ear, the rendering of the sound's three-dimensionality is not limited to headphone listening. This way these microphones use the wearer's body to render, through psychoacoustic principles normally involved in listening, an acoustic image that is much more spatialised than those we are used to with conventional stereo techniques. Furthermore, the microphone capsules have an excellent capacity for absorbing a wide range of sound pressures, thus getting close to the human ears in terms of dynamic range. Like lapel radio microphones, they are worn on the body, but their intended use could not be more different: DSM microphones are all about the recordist as a subject in the surroundings, whereas lavalier radio microphones are usually intended to minimise the interference of the surroundings with the subject's voice.

The aim of these omnidirectional microphones is not that of picking up as many sounds as possible, or to record more realistically if compared to human perception. I believe it would be a mistake to consider Feld's use of this equipment as finalized [or equivalent?] to the reproduction of "reality". As for wide angle lenses on a film camera, sometimes being able to embrace a wider field of view can result in a drawback, producing an image that is unappealingly chaotic. Rouch himself, who very often used wide angle lenses, warned his students against their misuses, which can lead to unwanted distortion and the disappearance of significant elements in the wide field of view. ${ }^{5}$ I would rather speak of an enhancement of hearing, a cyber-ear Feld uses to locate the listener, to have them move in space and appreciate aspects of sound that more traditional, less contextualizing recordings cannot represent. Listening to recordings such as The Time of Bells series (Feld 
CD 2004a; 2004b; 2005; 2007) becomes corporeal, thanks to the presence effect that once again represents an analogy with wide angle lenses.

The use of recording equipment in anthropology, and especially in ethnomusicology, has for a long time been that of producing documents to be analysed, a process that requires the isolation of sound sources from elements considered as disturbing. Obviously a choice such as Feld's entails sacrificing the perceptibility of single elements to the rendering of the whole. The aesthetic is anyway coherent: a sound recording made with DSM microphones has among its peculiarities the three-dimensionality of the acoustic image. As Gibson pointed out with regards to visual perception, three-dimensionality is better perceived in dynamic situations, where the eyes-head-body visual system interacts with the environment. So Feld's recording are dynamic, for the characteristics of the microphones push him to privilege situations where the recordist, or sonic elements around him, move. Conventional recordings, on the other hand, mirror a different model of cognition, one that privileges the accuracy of information by extracting the sound sources from their context and providing in this way a static, objectified and hardly locatable representation.

Feld's body, as for Rouch's wide angle, is used to perform deliberate effects: its movements in space change the balance of relative sound levels, while certain positions privilege some selected acoustic components, as for the reflections generated by certain surfaces. The body itself resounds, if placed in contact with vibrating surfaces, and Feld's face channels sound waves toward the microphones. I want to stress that this is not quite the same as mounting any device on somebody's person, since this alone does not guarantee much relationship with the perception of that body. A striking demonstration is represented by the film Leviathan (Castaing-Taylor and Paravel 2012), in which the filmmakers made large use of body cameras mounted on the crew of the fishing trawler where they filmed. In an interview they admit that the resulting images were disembodied because, although they were indexing an embodied experience, they lacked representational intentionality (cited in Hanssen 2015: 20). In Feld's recordings the researcher's body is instead perceived indirectly, being used to shape the recording and alter the balance of each sound source, and sometimes even directly, for the sounds he produces can be recorded. Feld addresses this issue in an interview with Gino Robair of the magazine eMusician:

[R:] On track 2 of The Time of Bells 1, I can clearly hear you walking and breathing, which is usually something avoided by field recordists. Did you have a problem overcoming that boundary or taboo?

[F:] No. I wanted that soundwalk to literally map my bodily orientation to the sound: arriving at the church parking lot and hearing that very austere and unique church bell; recording it full on; walking past to hear how it resounds against the church building; then walking through the big, heavy wooden church door and hearing its decay; and then sitting down and hearing, almost instantly, how the organ (one of the oldest pump organs in Finland) has an almost identical attacksustain-decay envelope. The recording technique - an audio version of the way one films in the cinéma vérité style, with the walking camera and focus on transition and juxtaposition - was a way to locate the bell vis-à-vis the organ. My own walking, breathing, sitting, and pulse are part of the experiential picture. Having that in there is a way to bring the listener right into the immediacy of my bodily experience of the sound. (Robair 2006)

Further, and similarly to Rouch's ciné-transe, this kind of recording affords a relationship of co-presence with those recorded. Feld started to reflect on these connections since the 
postscript of the second edition of Sound and Sentiment (Feld 1990), where he describes the process of revision and discussion of the book with the people involved in the fieldwork research. Since this dialogue his research pointed toward acoustic modalities of representing and sharing experience, up to the adoption of the DSM system that can be seen as a version of Rouch's participating camera.

The techniques I described, developed and learned through practice in the field, represent forms of embodiment of recording equipment. Such a situation involves the perception of a piece of equipment as an extension of one's own body, as an organ of mechanical perception whose use becomes almost unconscious, requiring nonetheless well-learned skills. Instead of considering organs as instruments, here instruments truly become supplementary organs $(1964,178)$. Such a conception of recording is very close to phenomenological ideas of being-in-the-world and to the premises of sensory ethnography.

27 I also would underline how the use of this equipment is not an end in itself, nor is it aimed at giving a more "faithful" or realistic idea of the field. The attitude developed by Rouch and Feld toward their recording techniques leads me to believe they considered recording a creative act, just like perception is active and creative in the conceptions of Gibson and Merleau-Ponty. Thus, mastering technology has the aim of providing evocative representations that are not necessarily realist in a conventional sense.

\section{Perception as Interaction} retrace in Rouch's and Feld's works contrasts with the more contemplative tradition of observational cinema, which has instead been reappraised as a filmic analogy with the renewed interest in anthropology for the senses and phenomenology (Grimshaw and Ravetz 2009: Chapter 5). Since these discussions often mention Merleau-Ponty's work on the phenomenology of perception, it is interesting to bring up a few points from his essay Eye and Mind (1964). Even though the text is centred on painting, Merleau-Ponty makes an argument that applies to visual representation in general and does not oppose painting and drawing to more indexical forms. For this reason I think it makes sense to extend his thinking not only to film but even to sound recording.

theory of vision described in Descartes' Dioptric, he writes, is mainly an intellectua process, a process of decoding the signs picked up by the body, instead of a reciprocal transformation in the act of seeing (Merleau-Ponty 1964: 170-171). For Descartes, continues Merleau-Ponty, drawings and paintings are imitations of a disembodied visual perception, they offer two-dimensional inputs, height and width, while depth is simply inferred from the two. But this third dimension, not present in the painting, is nothing but illusion, because for the Cartesian space has given, independent characteristics. For Merleau-Ponty on the other hand, as for Gibson, space is bound to the perceiver:

Space is no longer what it was in the Dioptric, a network of relations between objects such as would be seen by a witness to my vision or by a geometer looking over it and reconstructing it from outside. It is, rather, a space reckoned starting from me as the zero point or degree zero of spatiality. I do not see it according to its exterior envelope; I live in it from the inside; I am immersed in it. (Merleau-Ponty 1964: 178)

In common with Gibson's ecological perception, something links subject and object, seeing and seen, in a much deeper way than a mental image, or the internal 
representation of an external space. Merleau-Ponty questions the idea that the world is an "out there" and that the subject has to reconstruct its given properties. Quoting Cézanne's "La nature est à l'intérieur", he once again ties together body and world: "Quality, light, color, depth, which are there before us, are there only because they awaken an echo in our body and because the body welcomes them" (Merleau-Ponty 1964: 164). Painters work with their whole body, joining vision and movement, for the body always experiences reciprocity. The artist knows how to grasp and express this feeling of implication in things, less with faithful representation than creating. Writing about the rendering of movement, for example, Merleau-Ponty mentions Rodin to argue how snapshots of running athletes do not give the idea of movement, but rather freeze it. It is possible, instead, to evoke movement showing a human figure in a position that is not from a single instant, therefore not strictly realistic (Merleau-Ponty 1964: 185). I believe similar hyperrealistic procedures, in other words poetic interventions and augmented perception, should be applied to recording in anthropology, if we want images and sounds not to be read as texts but become sources of a different kind of knowledge. Nor do I believe that Merleau-Ponty is here making his argument against recorded media, but rather he is invoking a poetic intervention aimed at making of them artefacts evocative of perception, "an analogue or likeness only according to the body" (Merleau-Ponty 1964: 165).

31 Merleau-Ponty is arguing that a representation can be analogous to perception if it changes our way of seeing, working almost intersubjectively without trying to just be a copy of the world. It joins together seer and visible through the intercorporeality based on perception that makes the experience of the other accessible, thanks to a concept of the self as "caught up in things" (Merleau-Ponty: 163): perception is in fact a relational activity in Merleau-Ponty's thinking at least since La Structure du Comportement (1942). I find Rouch's and Feld's participant perspectives, as put in practice and described in this article, more suited to speak to such an understanding of perception than the unobtrusive camera style typical of observational cinema, which on the other hand is often described as related to phenomenology. Although Grimshaw and Ravetz (2009: 135) downplay its stylistic elements of in favour of epistemology and ethics, observational cinema's rendition of the filmmaker's engagement and co-presence is left to the filmic equivalent of a scholarly plain style (Henley 2004: 114-6), which encourages empiricist interpretations of the footage -- a debate that has characterised observational cinema since its inception. On the other hand, I believe that a recent filmic example is particularly well-suited to exemplify a participant embodied camera. Produced at Harvard's Sensory Ethnography Lab, Julia Yezbick's film Into the Hinterlands (2015) is composed of performances by the Detroit performance ensemble The Hinterlands. The filmmaker trained with the group and participated in their improvisational performances, something that had been set by the ensemble as a precondition for allowing her to make a collaborative film. The camerawork of the resulting piece is strikingly corporeal, being often as close to the performers as it gets, dancing with them and reacting to their movements as they integrate the cameraperson in the performance. Through long takes that are not strictly speaking realistic in their acrobatic overturnings, Yezbick manages to communicate the ecstatic and liminal nature of the performances thanks to her participation in them. 
This media file cannot be displayed. Please refer to the online document http://

Link: https://vimeo.com/166001290 and https://lorenzoferrarini.com/portfolio/living-the-weather/ (accessed August 6, 2017)

My own experimental documentary Living the Weather (Ferrarini 2016) draws inspiration from the aspects of Rouch's and Feld's work discussed above in five minute-long sequence shots. Using DSM microphones and an ultra-wide lens on a three-axis gimbal I follow the protagonists of each sequence in everyday activities, evoking their engagement with the weather and their surroundings. The sequences, agreed and performed collaboratively, emphasise perspective and dimensionality to maximise their immersive intent. The whole film project approaches weather from Gibson's ecological perspective and applies it to audiovisual media through maximising the situatedness of the recording perspective. Again, this is accomplished through devices that are not strictly realistic: a field of view much wider than human binocular vision points at Gibson's visual world, the spherical extension surrounding the perceiver that does not transform itself with to the perceiver's movements (1950: Chapter 3). The three-dimensional stereo image of the DSM microphones works in a similar way in the economy of these sequences. At the same time, I move very close to the people I film, sometimes interacting with them in a choreography that is more subtle than in Into the Hinterlands but no less participative.

\section{Conclusions}

These final examples sum up well the way in which I have provided an answer to the question of what makes an audiovisual ethnography a piece of sensory anthropology. First, to make a piece of sensory ethnography, an audiovisual ethnography should inscribe in itself the body of the maker, striving to evoke that corporeality in the audience. This principle responds to sensory ethnography's emphasis on the senses and embodiment as method and on the researcher's own experience as a tool. Rouch and Feld, two leading figures respectively in the fields of ethnographic cinema and sonic ethnography, have developed recording techniques and technologies that help this process of inscription and evocation. The methods they have developed can be put in dialogue with the stress that ecological theories of perception place on the differences between perception and recordings by making of the act of recording an active exploration, in which the body synaesthetically guides the rendition of the camera or sound recorder. This strategy also addresses phenomenology's emphasis on perception as act of reciprocal transformation, an element that is not only evident in the participant perspectives adopted by Rouch and Feld, but also in their development of dialogic and collaborative methods. So the second part of the answer to the initial question is that sensory ethnography should embrace interaction and participation to maintain a coherence between its anti-dualistic premises and its representational forms. The problem is similar to the correspondence between "disembodied observation" and "disembodied representation" remarked by Stoller for ethnographic writing (1997: xiii). An embodied camera (and/or microphone) has to be interactive because interaction is a fundamental component of embodied being-in-the-world. Not all interaction is mediated by linguistic channels, so sensory anthropology's interest for dimensions beyond text 
does not necessarily imply a strictly observational style. In Rouch's and Feld's work it is possible to notice multiple silent interactions ${ }^{6}$ that contribute to the embodied qualities of their productions. Their creative devices and strategies still show inspiring and promising ways for exploring the potential of audiovisual media to contribute to anthropology forms of knowledge that text might overlook.

\section{BIBLIOGRAPHY}

\section{Books and articles}

Bar-On Cohen, Einat. 2009. Kibadachi in Karate: Pain and Crossing Boundaries within the 'lived Body' and within Sociality. Journal of the Royal Anthropological Institute 15 (3): 610-629. doi:10.1111/ j.1467-9655.2009.01576.x.

Bordwell, David. 1993. The Cinema of Eisenstein. Harvard University Press.

Bynum, William F., and Roy Porter, eds. 1993. Medicine and the Five Senses. Cambridge University Press.

Classen, Constance. 1993. Worlds of Sense: Exploring the Senses in History and Across Cultures. London, New York: Routledge.

Clifford, James, and George E. Marcus. 1986. Writing Culture: The Poetics and Politics of Ethnography: A School of American Research Advanced Seminar. Berkeley: University of California Press.

Corbin, Alain. 1986. The Foul and the Fragrant: Odor and the French Social Imagination. Cambridge, Mass.: Harvard University Press.

Corbin, Alain. 1998. Village Bells: Sound and Meaning in the Nineteenth-Century French Countryside. New York: Columbia University Press.

Corrigan, Timothy. 2011. The Essay Film: From Montaigne, After Marker. New York: Oxford University Press.

Cox, Rupert A. 2011. Thinking through Movement: Practising Martial Arts and Writing Ethnography. In Redrawing Anthropology : Materials, Movements, Lines , T. Ingold, ed. Pp. 66-76. Farnham: Ashgate.

Cox, Rupert A., Andrew Irving, and Christopher Wright, eds. 2016. Beyond Text: Critical Practice and Sensory Anthropology. Manchester: Manchester University Press.

Csordas, Thomas J. 1990. Embodiment as a Paradigm for Anthropology. Ethos 18 (March): 5-47.

Csordas, Thomas J., ed. 1994. Embodiment and Experience : The Existential Ground of Culture and Self. Cambridge: Cambridge University Press.

Desjarlais, Robert. 1992. Body and Emotion: The Aesthetics of Illness and Healing in the Nepal Himalayas. University of Pennsylvania Press.

Downey, Greg. 2011. Learning the 'Banana Tree’: Self-Modification Through Movement. In Redrawing Anthropology : Materials, Movements, Lines, Tim Ingold, ed. Pp. 77-90. Farnham: Ashgate. 
Fabian, Johannes. 1983. Time and the Other : How Anthropology Makes Its Object. New York: Columbia University Press.

Feld, Steven. 1982. Sound and Sentiment: Birds, Weeping, Poetics, and Song in Kaluli Expression. Conduct and Communication Series. Philadelphia: University of Pennsylvania Press.

Feld, Steven. 1990. Postscript, 1989. In Sound and Sentiment : Birds, Weeping, Poetics, and Song in Kaluli Expression. Steven Feld, 2nd ed. Pp. 239-268. Conduct and Communication Series. Philadelphia: University of Pennsylvania Press.

Ferrarini, Lorenzo. 2009. "Registrare con il Corpo: dalla riflessione fenomenologica alle metodologie audio-visuali di Jean Rouch e Steven Feld." Molimo. Quaderni di Antropologia Culturale ed Etnomusicologia 4: 125-45.

Gibson, James J. 1950. The Perception of the Visual World. [With Illustrations]. Cambridge, Mass.: Riverside Press.

Gibson, James J. 1966. The Senses Considered as Perceptual Systems. Boston: Houghton Mifflin. Gibson, James J. 1979. The Ecological Approach to Visual Perception. Dallas , London: Houghton Mifflin.

Grimshaw, Anna and Amanda Ravetz. 2009. Observational Cinema: Anthropology, Film, and the Exploration of Social Life. Bloomington: Indiana University Press.

Hage, Ghassan. 2009. Hating Israel in the Field. On Ethnography and Political Emotions. Anthropological Theory 9 (March): 59-79. doi:10.1177/1463499609103547.

Hanssen, Eirik Frisvold. 2015. 'His Eyes Are Like the Rays of Dawn': Color Vision and Embodiment in Leviathan. Visual Anthropology Review 31 (1): 20-26. doi:10.1111/var.12058.

Henley, Paul. 2004. "Putting film to work: observational cinema as practical ethnography." In Working Images: Visual Research and Representation in Ethnography, eds Sarah Pink, Lászlo Kürti, and Ana Isabel Afonso, 109-130. London: Routledge.

Henley, Paul. 2009. The Adventure of the Real: Jean Rouch and the Craft of Ethnographic Cinema. Chicago and London: University of Chicago Press.

Herzfeld, Michael. 2001. Anthropology: Theoretical Practice in Culture and Society. Malden MA: Blackwell.

Heuson, Jennifer L. and Kevin T. Allen. 2014. Asynchronicity: Rethinking the Relation of Ear and Eye in Ethnographic Practice. In Experimental Film and Anthropology. Arnd Schneider and Caterina Pasqualino, eds. Pp. 113-30. London and New York: Bloomsbury Academic.

Howes, David. 1991. The Varieties of Sensory Experience: A Sourcebook in the Anthropology of the Senses. Toronto and London: University of Toronto Press.

Howes, David. 2003. Sensing Culture: Engaging the Senses in Culture and Social Theory. Ann Arbor: University of Michigan Press.

Howes, David. 2005. Empire of the Senses: The Sensual Culture Reader. Oxford and New York: Berg. Ingold, Tim. 2000. The Perception of the Environment: Essays on Livelihood, Dwelling and Skill. London: Routledge.

Ingold, Tim. 2004. Culture on the Ground The World Perceived Through the Feet. Journal of Material Culture 9 (3): 315-40. doi:10.1177/1359183504046896.

Ingold, Tim. 2007. Against Soundscape. In Autumn Leaves: Sound and the Environment in Artistic Practice, ed. A. Carlyle. Paris: Double Entendre. 
Ingold, Tim. 2011a. Being Alive: Essays on Movement, Knowledge and Description. Taylor \& Francis.

Ingold, Tim. 2011b. "Worlds of Sense and Sensing the World: A Response to Sarah Pink and David Howes.” Social Anthropology 19 (3): 313-17. doi:10.1111/j.1469-8676.2011.00163.x.

Jackson, Michael. 1983. Knowledge of the Body. Man 18: 327-45.

Jackson, Michael. 1989. Paths toward a Clearing : Radical Empiricism and Ethnographic Inquiry. African Systems of Thought. Bloomington: Indiana University Press.

Jackson, Michael. 1996. Things as They Are : New Directions in Phenomenological Anthropology. Bloomington: Indiana University Press.

Kirmayer, Laurence J. 1992. The Body's Insistence on Meaning: Metaphor as Presentation and Representation in Illness Experience. Medical Anthropology Quarterly 6 (4): 323-346. doi:10.1525/ maq.1992.6.4.02a00020.

Kohn, Tamara. 2001. "Don't Talk - Blend”: Ideas about Body and Communication in Aikido Practice. In An Anthropology of Indirect Communication, J. Hendry and C. W. Watson, eds. Pp. 163-68. London: Routledge.

MacDougall, David. 2016. Observational Cinema. In Anthropology Beyond Text. Vol. 12. International Encyclopaedia of Anthropology. New York: Wiley-Blackwell.

MacDougall, David. 2006. The Corporeal Image: Film, Ethnography, and the Senses. Princeton, N.J. and Oxford: Princeton University Press.

Merleau-Ponty, Maurice. 1942. La Structure du Comportement. Paris: Presses universitaires de France.

Merleau-Ponty, Maurice. 1964. Eye and Mind. In The Primacy of Perception: And Other Essays on Phenomenological Psychology, the Philosophy of Art, History, and Politics, translated by Carleton Dallery. Pp. 159-92. Evanston, IL: Northwestern University Press.

Newmahr, S. 2008. Becoming a Sadomasochist - Integrating Self and Other in Ethnographic Analysis. Journal of Contemporary Ethnography 37 (October): 619-43. doi:10.1177/0891241607310626. Pink, Sarah. 2004. Home Truths: Gender, Domestic Objects and Everyday Life. New York: Berg. Pink, Sarah, and David Howes. 2010. The Future of Sensory Anthropology/The Anthropology of the Senses. Social Anthropology 18 (3): 331-40. doi:10.1111/j.1469-8676.2010.00119_1.x.

Porter, Roy. 2005. Flesh in the Age of Reason. New York: W.W. Norton \& Co.

Rice, Timothy. 1994. May it Fill Your Soul: Experiencing Bulgarian Music. Chicago: University of Chicago Press.

Robair, Gino. 2006. In the Time of Bells With Steven Feld. http://www.emusician.com/ artists/1333/in-the-time-of-bells-with-steven-feld/36204. (accessed August 6, 2017)

Rosaldo, Renato. 1984. Grief and a Headhunter's Rage: On the Cultural Forces of Emotion. In Text, Play, and Story: The Construction and Reconstruction of Self and Society, E. M. Bruner, ed. Pp. viii, 364 p. Washington, D.C.: American Ethnological Society.

Roseman, Marina. 1993. Healing Sounds From the Malaysian Rainforest: Temiar Music and Medicine. University of California Press.

Rouch, Jean. 2003a. On the Vicissitudes of the Self: the Possessed Dancer, the Magician, the Sorcerer, the Filmmaker, and the Ethnographer. In Ciné-Ethnography. Steven Feld translation. Pp. 87-101. Visible Evidence Series Vol. 13. Minneapolis: University of Minnesota Press. 
Rouch, Jean. 2003b. The Camera and Man. In Ciné-Ethnography. Steven Feld translation. Pp. 29-46 Visible Evidence Series Vol. 13. Minneapolis: University of Minnesota Press.

Sanders, J. T. 1993. Merleau-Ponty, Gibson, and the Materiality of Meaning. Man and World - an International Philosophical Review 26 (July): 287-302.

Scheper-Hughes, Nancy and Margaret Lock. 1987. The Mindful Body: A Prolegomenon to Future Work in Medical Anthropology. Medical Anthropology Quarterly : 6-41.

Seremetakis, C. Nadia. 1996. The Senses Still. Chicago: University of Chicago Press.

Smith, Mark Michael. 2007. Sensing the Past: Seeing, Hearing, Smelling, Tasting, and Touching in History . University of California Press.

Stoller, Paul. 1984. Sound in Songhay Cultural Experience. American Ethnologist 11 (3): 559-570. doi:10.1525/ae.1984.11.3.02a00090.

Stoller, Paul. 1989. The Taste of Ethnographic Things: The Senses in Anthropology. Philadelphia: University of Pennsylvania Press.

Stoller, Paul. 1992. The Cinematic Griot: The Ethnography of Jean Rouch. Chicago: University of Chicago Press.

Stoller, Paul. 1997. Sensuous Scholarship. Philadelphia: University of Pennsylvania Press.

Stoller, Paul and Cheryl Olkes. 1987. In Sorcery's Shadow: A Memoir of Apprenticeship Among the Songhay of Niger. Chicago and London: University of Chicago Press.

Suhr, Christian and Rane Willerslev. 2012. Can Film Show the Invisible?: The Work of Montage in Ethnographic Filmmaking. Current Anthropology 53 (3): 282-301. doi:10.1086/664920.

Taylor, Julie M. 1998. Paper Tangos. Duke University Press.

Wacquant, Loïc. 1995. The Pugilistic Point of View: How Boxers Think and Feel about Their Trade. Theory and Society 24 (4): 489-535.

Wacquant, Loïc. 2004. Body \& Soul: Notebooks of an Apprentice Boxer. Oxford University Press.

Wulff, Helena. 1998. Ballet Across Borders: Career and Culture in the World of Dancers. New York: Berg.

Films

Castaing-Taylor, Lucien and Véréna Paravel, dirs. 2012. Leviathan Cinema Guild et al. USA

(production). $87 \mathrm{~min}$.

Ferrarini, Lorenzo. 2016. Living the Weather - Five Variations on Weather and Seasons in the Calder Valley. 4K Digital Video. https://lorenzoferrarini.com/portfolio/living-the-weather/ (accessed November 11, 2016)

Rouch, Jean. 1971 Tourou et Bitti: Les Tambours d'Avant. CNRS, France (production). 9 min.

Rouch, Jean and Edgar Morin 1960 Chronique d'un été, Argos Films, France (production). 90 min. Vertov, Dziga. 1924 The Cine-Eye. UdSSR (production). 52 min.

Yezbick, Julia. 2015. Into the Hinterlands. Harvard Film Sudy Center and the Sensory Ethnography Lab, USA (production). 39 min. http://www.intothehinterlands.com/ (accessed November 11, 2016)

\section{Sound recordings}

Feld, Steven. 2004a The Time of Bells, I: Soundscapes of Italy, Finland, Greece and France, CD - Santa Fe, NM: Voxlox Documentary Sound Art. 
Feld, Steven. 2004b The Time of Bells, II: Soundscapes of Finland, Norway, Italy and Greece, CD - Santa

Fe, NM: Voxlox Documentary Sound Art.

Feld, Steven. 2005 The Time of Bells, III: Musical Bells of Accra, Ghana, CD - Santa Fe, NM: Voxlox

Documentary Sound Art.

Feld, Steven. 2007 The Time of Bells, IV: Soundscapes of Italy, Denmark, Finland, Japan and Iraq/USA, CD

- Santa Fe, NM: Voxlox Documentary Sound Art.

\section{NOTES}

1. This text contains revised and translated portions of the article I published in Italian with the title Registrare con il corpo: dalla riflessione fenomenologica alle metodologie audio-visuali di Jean Rouch e Steven Feld (Ferrarini 2009).

2. Even though he never references any European phenomenologist, Gibson shares with MerleauPonty an intellectual kinship in gestaltist psychology, that shows through many quotations from Koffka. A thorough analysis of the main points in common between Gibson and Merleau-Ponty can be found in Sanders (1993).

3. Steven Feld, personal communication, 16 September 2007. I also had an exchange with Heike Behrend who told me of her memories of a masterclass in "camera gymnastics" she attended in Nanterre in the mid-1970s, where Rouch was teaching movements with the camera, in collaboration with a choreographer (personal communication, 14 October 2014).

4. For more information, visit the manufacturer's website: http://www.sonicstudios.com

5. Steven Feld, personal communication 16 September 2007.

6. Rouch's short film Tourou et Bitti (1971) is probably the most unique example. Filming with cinéma-vérité techniques, Rouch shoots a single nine minute roll of film, influencing the unleashing of a possession crisis with his presence.

\section{ABSTRACTS}

This article represents a reflection on the application of the perspective provided by sensory ethnography to audiovisual media productions. It starts from the debate on anthropology of the senses and sensory ethnography to underline the importance of the rendition of a recording body in a film or sound recording. The text then reviews examples from the work of Jean Rouch and Steven Feld, underlining how they developed specific recording technologies that allowed them to give to their media work an embodied character. Finally, the article approaches the relationship between sensory media and interaction through engagement with the work of Merleau-Ponty, stressing how from a phenomenological perspective an embodied camera is always an interactive camera.

Cet article présente une réflexion sur l'application de l'ethnographie sensorielle dans le cadre de la production audiovisuelle. A partir des débats qui ont été menés autour de l'anthropologie des sens et de l'ethnographie sensorielle l'auteur aborde l'importance de l'interprétation d'un corps enregistrant dans un film ou dans une bande son. Cet article tout en s'inspirant des oeuvres de Jean Rouch et de Steve Feld, souligne la manière dont ils ont développé des techniques 
spécifiques qui leur ont permis dans le cadre de leur production une dimension corporelle. Finalement, l'article développe les relations entre les médias sensoriels, l'interaction et l'engagement à partir des recherches de Merleau Ponty, qui souligne comment d'un point de vue phénoménologique une caméra incarnée est toujours une caméra interactive.

Este artículo representa una reflexión sobre la aplicación de la perspectiva proporcionada por la etnografía sensorial a las producciones de medios audiovisuales. Comienza con el debate sobre la antropología de los sentidos y la etnografía sensorial para subrayar la importancia de la acción del cuerpo como agente de grabación en una película o grabación de sonido. El texto luego revisa ejemplos del trabajo de Jean Rouch y Steven Feld, subrayando cómo desarrollaron tecnologías de grabación específicas que les permitieron dar a su trabajo con los medios un carácter corporal. Finalmente, el artículo aborda la relación entre los medios sensoriales y la interacción con el trabajo de Merleau-Ponty, destacando cómo, desde una perspectiva fenomenológica, una cámara incorporada es siempre una cámara interactiva.

\section{INDEX}

Mots-clés: ethnographie sensorielle, anthropologie visuelle, Jean Rouch, Steven Feld, sens, incarnation, technologies, perceptions, Jame J.Gibson

Palabras claves: etnografía sensorial, antropología visual, Jean Rouch, Steven Feld, sentidos, corporalización, tecnología, percpeción, Janes G. Gibson

Keywords: sensory ethnography, visual anthropology, Jean Rouch, Steven Feld, senses, embodiment, technology, perception, James J. Gibson

\section{AUTHOR}

\section{LORENZO FERRARINI}

University of Manchester, Granada Centre for Visual Anthropology

lorenzo.ferrarini@manchester.ac.uk 